\title{
Promoting Pre-service Second Language (L2) Teacher Learning via Narrative: A Sociocultural Perspective
}

\author{
Ekaterina Arshavskaya \\ Utah State University, USA \\ Anne Elrod Whitney \\ Pennsylvania State University, USA
}

\begin{abstract}
This study constitutes a qualitative investigation of a series of interactions between an experienced teacher educator and a pre-service teacher in the context of a teaching English as a second language (ESL) practicum blog. The study demonstrates how the activity of writing a dialogic blog can facilitate teacher professional development. Responding to the recent call to investigate the ways in which teacher engagement in writing (Johnson \& Golombek, 2011) can assist teacher learning and given the urge to promote conceptual ways of understanding teaching on the part of the novice teachers (Johnson, 2009), this paper presents a case study that shows both the novice's growth as expressed through writing and reflection in the blog as well the teacher educator's moves designed to foster the novice's learning. A sociocultural perspective on human cognitive development (Vygotsky, 1978) was used as a theoretical framework for tracing the novice's development and capturing the transformative power of the novice's narration as well as the characteristics of the teacher educator's mediation. Our findings indicate that when the teacher educator's mediation is strategically designed, engagement in narrative through a dialogic blog can be a powerful tool for stimulating a novice's more expert understanding of ESL teaching and encouraging the application of that understanding in practice.
\end{abstract}

Index Terms - dialogic teacher blog, teacher narrative, meditational space, externalization, verbalization

\section{INTRODUCTION}

Recent perspectives on the nature of teacher knowledge reject a technicist view of teaching and regard teachers as reflective practitioners (Feiman-Nemser, 2001) who learn in and from their practice using reflective tools to learn from and change teaching practice (Johnson, 2009; Mann, 2005). In this view, teacher-authored accounts of their beliefs and practices are legitimate forms of teacher knowledge (Johnson, 2009), and teachers are positioned not as passive recipients of knowledge but as its active producers and users (Cochran-Smith \& Lytle, 1993). During the last 20 years, researchers have suggested that teachers' narratives can play a critical role in deepening teacher understanding of teaching and learning and promoting teacher inquiry into the lives of their students. Recently, Johnson and Golombek (2011) developed an analytical framework to examine the ways in which teacher narrative promotes learning of English as a second language (ESL) teachers. For Johnson and Golombek (2011), narrative fosters teacher professional development by igniting cognitive processes that can be understood according to three broad and sometimes overlapping categories: externalization, verbalization, and systematic examination.

These ideas have, in turn, prompted a call for research that documents the complex ways in which second language (L2) teachers learn through their own reflections in teacher-authored narratives (Johnson \& Golombek, 2011; Park, 2013; Verity, 2000). Here, we will describe just such a study, analyzing a pre-service L2 teacher's interactions with her practicum supervisor in the context of a dialogic blog. Our analysis offers a portrait of a beginning teacher who over time seeks out more and more assistance for herself (and from wider sources), works through the emotional challenges of teaching in the context of a relationship with the supervisor, and tentatively begins to engage in and draw on expert discourse. Importantly, the study also highlights the characteristics of the experienced teacher educator's mediation in terms of its focus on promoting the novice's more conceptual understanding of teaching. The study thus focuses on the nature of the interaction between the teacher educator and the novice within the teaching practicum blog as well as the features of the teacher educator's mediation, leading to the novice's initial efforts to transform her L2 teaching practices.

The purpose of this paper is to examine the role of narrative supported by the mediation of the experienced teacher educator in the pre-service teacher's development of a more expert understanding of L2 teaching and learning. Given the importance of promoting teacher conceptual understanding of teaching (Johnson, 2009), we explored the nature of the expert teacher educator's mediation in terms of fostering the novice's efforts to achieve a more expert understanding of teaching. In order to trace the changes in how the teacher understands teaching over the period of a one-semester practicum, we used Johnson and Golombek's (2011) framework as a tool to explore the cognitive functions 
(externalization, verbalization, and systematic examination) evident in the novice's blog. We found that both the narrative and the teacher educator's mediation each played a crucial part in enhancing the novice's understanding of L2 learning and teaching and helping her apply those understandings in her actual practice. Our study, therefore, extends current research on the use of narrative and teacher educator's mediation to promote teacher learning. The significance of this paper is that it provides new insights for faculty in teacher education programs who are designing and implementing teacher practicums with the use of dialogic blogs and for researchers who seek to understand how teachers learn through narrative.

\section{LITERATURE REVIEW}

\section{A sociocultural perspective on teacher learning}

We view the interaction between the experienced and the novice teacher through sociocultural theory, which as a theory of human cognitive development serves as an ideal lens through which to "see" teacher learning (Johnson \& Golombek, 2003). According to a sociocultural theoretical perspective, human cognitive development occurs through participation in the activities of a given society, with language playing a major role. Vygotsky (1987) was particularly aware of the power of writing for the overall development of human thought. This power stems in large part from the way writing externalizes thought and makes it visible and, therefore, subject to conscious examination and manipulation. According to Lantolf and Thorne (2006), for example, when children learn to write, they "make their thinking fully explicit, if it is to be apprehended by their audience; [and] in so doing, they are at the same time making this thinking visible to themselves" (p. 293). Likewise, through writing in a teaching practicum blog, a pre-service teacher can make her own tacit beliefs about teaching fully explicit to herself and also open them up for the dialogic mediation of a more expert other (i.e., the teaching practicum supervisor).

The sociocultural theory also underscores the crucial role that expert mediation plays in promoting cognitive development. By mediation, we mean "the process through which humans deploy culturally constructed artifacts, concepts, and activities to regulate (i.e., gain voluntary control and transform) the material world or their own and each other's social and mental activity" (Lantolf \& Thorne, 2006, p. 79). Informed by the sociocultural perspective on teacher education, recent research in the field of L2 teacher education argues that teacher education programs should mediate pre-service teachers' development of a conceptual understanding of teaching (Johnson, 2009). Teachers can achieve this by externalizing their everyday conceptions of teaching and then connecting these conceptions to researchbased (scientific) concepts at the backdrop of concrete activities (Johnson, 2009).

In Vygotsky's (1963) view, everyday concepts form during practical activities and are less systematic or generalizable than research-based (scientific) concepts and are open to conscious inspection (see also Johnson, 2009). In contrast, research-based (scientific) concepts are defined as "the generalizations of the experience of humankind that is fixed in science, understood in the broadest sense of the term to include both natural and social sciences as well as humanities" (Karpov, 2003, p. 66). In the context of L2 pre-service teacher education, then, scientific concepts (Vygotsky, 1963) are constituted by subject matter (what to teach) and pedagogical concepts (how to teach). For example, within an L2 writing course, subject matter concepts include the concept of the genre of an academic essay (e.g., expository, persuasive, or argumentative), whereas an example of a related pedagogical concept has to do with the methods used to teach the students how to produce the genre of the academic essay.

Further, it is important that these research-based (scientific) concepts be grounded in the actual activities of teaching (Johnson, 2009). According to Johnson (2009), the internalization of research-based (scientific) concepts can be defined as "a process through which a person's activity is initially mediated by other people or cultural artifacts but later comes to be controlled by the person as he or she appropriates and reconstructs resources to regulate his or her own activities" (p. 33). At the same time, Vygotsky (1986) emphasized that internalization is not a straightforward process from the outside in, but a transformative process whereby a person's (in this case, the teacher's) cognitive structure changes such that changes in her teaching activities follow (Leont'ev, 1981; Valsineer \& van der Veer, 2000).

\section{Using narrative to promote teacher learning}

Previous research in the context of L2 teacher education has established the utility of reflective autobiographical accounts related to teaching (Golombek \& Johnson, 2004; Johnson \& Golombek, 2002) or journals in which teachers describe and reflect on their everyday instructional decisions and practices (e.g., Bigelow \& Ranney, 2005; Johnson, 1994; Numrich, 1996). Reflective writing is an inquiry-based professional development activity whereby a space is created in which teachers can reflect on their teaching beliefs and practices, re-frame their current understandings of teaching, and search for alternative ways of engaging in everyday teaching practices. Borg (2006) notes that "journals and autobiography in particular have been widely employed to support and study teachers' understandings of their own learning and practices," underscoring that writing helps "make ... tacit mental processes explicit and hence available for examination" (p. 250). By externalizing their tacit thoughts and feelings about their teaching beliefs and practices, teachers act as reflective practitioners (Schön, 1987) who learn in and from their practice.

Engagement in writing about one's teaching practices has been found to be effective for stimulating both experienced and inexperienced teachers to reflect on and even make changes to their classroom activities. For example, Golombek and Johnson (2004) showed how a pre-service teacher's engagement in a narrative activity allowed her to connect some of the concepts from her theoretical Teaching English as a Second Language (TESL) graduate coursework to her 
practical experiences in the classroom, helping her to make sense of her teaching experiences and externalize an idealized conception of what she would like to do in her future teaching. Likewise, Verity (2000) showed how through self-reflective writing an experienced educator regained her sense of expertise in an unfamiliar instructional context (Japan).

In this study, we will explore the role of writing in the development of a pre-service teacher's expertise in L2 teaching as well as the impact of her supervisor's mediation in the context of a dialogic blog. This article offers a sociocultural analysis of the dialogic interactions between an L2 pre-service teacher and her supervisor in an online dialogic teaching practicum blog, with a specific focus on the supervisor's impact on the novice's development of teaching expertise. Given the well-documented affordances of engagement in narrative activities for teacher development, how, if at all, does the pre-service teacher draw on the supervisor's expertise in the context of their written dialogue? As the following analysis shows, over time and as the pre-service teacher moved into field experience, she shifted from simply receiving mediation from the supervisor to eliciting and engaging mediation from the supervisor as well as from her mentor teacher and peers. This shift in the way the pre-service teacher sought mediation unfolded in the context of a developing supportive emotional relationship. In addition, we witness such processes as externalization, verbalization, and systematic inquiry as well as a transfer of knowledge from the dialogic exchanges to the actual novice's classroom, which points to the effectiveness of the supervisory mediation.

\section{THE STUDY}

\section{Context of the study}

The data for the study are from the online dialogic blog entries between a pre-service teacher interning in a master of arts (MA) in TESL program at a large northeastern American university and her supervisor. The data were collected over the period of one semester (January 2008 to May 2008). At the time of the data collection, the pre-service teacher, Kristina, was enrolled in the MA TESL program at the same university. Before she took the internship, Kristina had taught English in an elementary school. The supervisor, Melanie, is a professor at the same university with extensive experience in ESL teaching and in supervising and mentoring MA TESL pre-service teachers.

During the practicum, Kristina was placed in an ESL course offered to prospective international teaching assistants (ITAs) preparing to teach at the university. This class was taught by Elaine, who served as Kristina's mentor teacher. Kristina was required to observe Elaine teaching, practice teach several classes herself, and post her observations and reflections in the teaching practicum blog, to which the supervisor (Melanie) then regularly responded.

\section{Mode of inquiry}

Our mode of inquiry was informed by grounded theory (Bogdan \& Biklin, 1992; Glaser \& Strauss, 1967). Specifically, we read the blog entries multiple times in order to identify the key phrases and sentences that represented Kristina's evolving understandings of her teaching experiences and Melanie's attempts to further mediate the novice's conceptions of L2 teaching. The blog entries were then coded based on recurring concepts and patterns. The analysis was also guided by previous research on L2 teacher learning (Johnson \& Golombek, 2011; Golombek \& Johnson, 2004; Johnson, 2009). We were particularly interested in the cognitive processes that the novice exhibited through writing in the blog. According to Johnson and Golombek (2011), the cognitive processes ignited by engagement in the narrative activity include the following: externalization, verbalization, and systematic examination of one's teaching practices.

Through externalization, teachers can express their understandings, feelings, and perceptions of teaching and students and make sense of their experiences and the day-to-day problems that occur in their practice. Thus, teachers can "make their understandings explicit to themselves and to others" (Johnson \& Golombek, 2011, p. 491). Through verbalization, teachers can internalize knowledge, concepts, and theory. And, through narrative, teachers verbalize connections between day-to-day events and theory. Finally, through systematic examination, teachers engage in pre-determined narrative activities structured to promote inquiry into daily practice.

\section{RESUlts AND ANALysis}

\section{Portrait of the Novice's Learning in the Context of the Dialogic Practicum Blog}

Overall, Kristina (the novice teacher) began by simply receiving Melanie's assistance only when initiated by Melanie (the experienced teacher). However, over time, Kristina gradually transitioned to seeking assistance-both from Melanie and from others such as her mentor Elaine and her peers in the program. This transition took place against a background of Kristina's emotional dissonance and Melanie and Kristina's development of trust and emotional openness between each other. In time, Kristina began to draw explicitly on expert knowledge in ways that point to an emerging ability to claim expert discourse as her own. Importantly, in her blog entries, Kristina was able to re-voice the teacher educator's discourse and to incorporate the teacher educator's ideas into her teaching practice.

In addition, we see how through contributing to the dialogic blog, Kristina externalizes her current understandings of teaching, systematically inquires into her teaching practices, and verbalizes, i.e., connects some of the theoretical concepts of teaching to her own observations of teaching, and even incorporates into her practice some of the pedagogical concepts provided by her supervisor via the blog. The narrative provided the teacher with opportunities to connect theory and concepts to her teaching practice. Further, according to Johnson and Golombek (2011), for teachers 
to engage in systematic examination, narrative activities must allow for self-directed, collaborative, and inquiry-based learning connected to teachers' day-to-day experiences. Our findings indicate evidence of this systematic examination of Kristina's teaching practices through her engagement in the narration and reflection in the blog. Consistent with the analytical framework suggested by Johnson and Golombek (2011), Kristina systematically considered her own teaching practice and made decisions about how she might alter it.

In particular, in terms of the cognitive processes ignited through Kristina's engagement in the written narrative of her teaching experiences, we could witness the externalization of her emotions and feelings with regard to her teaching and the supervisor's attempts to connect those everyday conceptions of teaching to more expert conceptualizations. In her last entries in the blog, we also see Kristina verbalizing the concepts described by her supervisor (i.e., instructional paraphrasing, situating an instructional activity, and developing a teaching persona) and reporting on incorporating those concepts in her subsequent classroom teaching practices. Finally, throughout the course of the internship, Kristina participated in a process of systematically examining her teaching activity, which led her to gradually seek more assistance from the wider community of educators (her mentor teacher and the supervisor) as well as to incorporate the materials and ideas of her supervisor in her instructional activities with the goal of improving her teaching practices. Overall, Kristina's learning progressed as follows: She (1) externalized her thoughts and feelings, (2) recognized the loss of self-regulation, (3) experienced emotional dissonance in regard to her first-time teaching, (4) incorporated Melanie's pedagogical concepts of teaching and became conscious of her own learning, and (5) verbalized her understandings of teaching using expert discourse.

In the sections that follow, Kristina's perceptions and understandings and the supervisor's attempts to further mediate her learning will be identified in excerpts from the dialogic blog.

\section{Externalizing thoughts and feelings}

In her initial blog entries, Kristina mainly expressed her thoughts and feelings related to observing and teaching in the ITA course. In the following excerpt, we see her first reactions. Interestingly, Kristina shares a very positive response, saying that she has "now understood what the ... class is all about." (Blog entry, 29 January 2008)

After talking to Elaine and observing the class and the corresponding material, I have now understood what the ... class is all about - using language (English) and the improvement of, as a foundation, this course is to help students become better aware of the American culture as well as their own teaching in relation to their academic setting they hope to be involved with. [italics indicate emphasis added] (Blog entry, 29 January 2008)

Likewise, in her subsequent blog entry, Kristina continues to relate her reactions to observing the ITA course. In particular, she focuses on the composition of the class, the students' countries of origin, and some of the concerns the students shared.

Interestingly enough the class is made up of ALL Chinese students with the exception of 1 Thai, and 1 Mexican (male) students. The class is fairly evenly divided into half female, half male as well.... Some of the concerns that students mainly had were the following: Understanding HOW to be a TA in the American university. They were frustrated because students were always saying things like, "I don't understand you" over and over again when they're trying to explain it. They realize that it wasn't necessarily their language, but it's HOW they talk with the students and HOW they relay information. (Blog entry, 5 February 2008)

Thus, at least initially, Kristina uses the blog to externalize her emotions and thoughts. However, as her practicum unfolds, she starts to use the blog to identify her instructional concerns and their roots.

In her response to this entry, Melanie attempts to re-direct Kristina's attention to how the course might help these students start to re-position themselves. In addition, during this initial period of the teaching practicum, Kristina does not request mediation (assistance) from an expert other (her supervisor). Instead, it is Melanie who poses a question to Kristina.

As you continue to observe and work with these students see if you can get a sense of how what they are learning will help to reposition themselves - and see if you can get a sense of how this repositioning ... is changing the way they see themselves as second language users, as potential ITAs, and as future teachers. (Blog entry, 6 February 2008)

Yet, in her subsequent entry, Kristina fails to return to the issue of how participating in the ESL course might enable the ESL students to re-position themselves. Melanie again attempts to elicit Kristina's response to this issue. This time, the supervisor's mediation is more explicit.

Do they [the teacher and students in the ESL course] talk about how undergraduates view them [the ITAs] or what expectations undergrads may have? Do they talk about how their departments view them? Or other TAs [teaching assistants] in their departments?... Do any of these issues make it into the ... curriculum? (Blog entry, 20 February 2008)

It is likely that upon seeing Kristina's unresponsiveness to her earlier mediational move, the supervisor decides to recalibrate (Lantolf \& Thorne, 2006) her mediation: she makes it more explicit. In her earlier entry, the supervisor merely suggests a focus for Kristina's observation, whereas in her second entry during this early period of the teaching practicum, she asks more questions related to the actual activities and topics to which students are exposed in this course.

In her next entry, Kristina demonstrates her responsiveness to her supervisor's more explicit mediation: she tells Melanie about an assignment that had helped the students start reflecting on how undergraduate students view them. 
I don't think there was any discussion about how they are viewed within their own departments or by their colleagues. However, during their presentation ... they did have to go and talk with faculty and peers about what is typically seen as a "good" TA. (Blog entry, 21 February 2008)

Overall, during this initial period of the teaching practicum, Kristina did not seek mediation from her supervisor. At the same time, her moves shifted from unresponsive to responsive. Initially, Kristina did not reply to her supervisor's request to reflect on how the ESL students' participation in the course she observes allowed them to re-position themselves. Even though it is not clear why Kristina remained unresponsive to the given mediation, it is plausible that due to her limited teaching experience, Kristina needed more explicit mediation to prompt her to respond. Finally, we saw how the blog served as a tool through which Kristina externalized her initial thoughts about the course, whereas Melanie mediated and re-directed those initial understandings, to which Kristina became gradually responsive.

\section{Recognizing the loss of self-regulation}

During the next period of the teaching practicum, Kristina assisted her mentor, Elaine, with evaluating the students' oral presentations. In her entry during this period, Kristina requested her supervisor's assistance. In other words, she experienced and expressed a need for mediation from a more expert other (Melanie).

There was no rubric and being a novice, I didn't feel like I could give them an objective assessment. If there was a criteria that I could follow, I think I would have felt more comfortable. (Blog entry, 20 February 2008)

In her response, Melanie offers to share some grading rubrics. In her subsequent entry, Kristina accepts the supervisor's help. From a sociocultural perspective, Kristina experienced needs in regard to both object-regulation (grading rubrics) and other-regulation (the supervisor). Kristina also used her supervisor as a resource (Golombek, 2011): the supervisor provided her with concrete grading rubrics that Kristina could use in her teaching.

\section{THAT WOULD BE GREAT!}

I actually was meaning to ask you for the rubric that you use for the oral proficiency interview. If you don't mind, I would like to start using that for this class (next time they present), and also for another assignment (... language testing). That's why I didn't feel very comfortable about evaluating them. I just felt that it was based on just my prior knowledge of what I think is needed, rather than being objective and consistent. Hopefully this will be able to help. (Blog entry, 20 February 2008)

At this stage, Kristina seems unable to function without external assistance. The entry above expresses Kristina's reliance on her supervisor's assistance in order to assign appropriate grades to the students' oral presentations. Thus, Kristina's entries created opportunities for her to engage in introspection and sense-making and to explore the day-today problems (evaluating student presentations) she was experiencing in her teaching. Furthermore, Kristina's blog represents a mediational space for thinking in which through externalizing and making explicit her thoughts and feelings, we see her struggle to develop her self-regulation.

Overall, due to Kristina's engagement in the practices of teaching (evaluation of students' oral presentations), the nature of her interactions with the supervisor changed. This time, Kristina initiated a request for mediation from the supervisor. From a sociocultural perspective, by vocalizing their need for assistance, learners take greater responsibility for their own learning. It is also important to note that it is engagement in actual teaching that drove Kristina to search for assistance, which confirms the Vygotskian claim about the nature of human development, i.e., that human cognition originates through human involvement in the actual social activities of a given society. Furthermore, Kristina continued to respond to the supervisor's assistance: she decided to use the rubrics Melanie shared with her in her own teaching. Finally, after realizing a loss of self-regulation in teaching, Kristina was able to regain her sense of expertise by relying on her supervisor's assistance. As Golombek and Johnson (2004) argue, teacher educators should play a crucial role in prompting and supporting the novices' development of teaching expertise, which indeed is demonstrated in this case study.

\section{Self-sought mediation from the mentor teacher and the supervisor}

As the practicum unfolded, Kristina taught several ESL classes in the course that she observed her mentor (Elaine) teach. Interestingly, Kristina not only sought mediation from her supervisor, but also from her mentor teacher and a peer. This shows her agency as a learner of teaching. She also appealed to expert knowledge (Kennedy, 1999) in order to support her opinion. Thus, Kristina's development as a teacher during the teaching practicum was dependent on her access to and agency in appropriating various mediational means. Kristina made use of various forms of social mediation, e.g., a peer, her mentor, and expert knowledge (Kennedy, 1999). By making this explicit connection to the theories and concepts from her graduate coursework in TESL, Kristina connected educational theory to the practice of L2 teaching.

As noted, during this period of the teaching practicum, Kristina continued to initiate mediation from expert others, specifically, her mentor and her supervisor.

I really want to get feedback from Elaine first, work on that.... I really want to think of something that will engage students.... If you [Melanie] have suggestions on how students could be engaged in doing an analysis of a transcript, your input would be greatly appreciated. I have uploaded the transcript we are using. (Blog entry, 25 February 2008)

This entry demonstrates Kristina's awareness of her need for other-regulation. This time, Kristina sought assistance from both Melanie and Elaine. Apparently, it was Kristina's engagement in the actual activities of teaching that induced 
this change. In her response, Melanie made concrete suggestions regarding how Kristina could use the transcript in her ESL class. In addition, Melanie shared with Kristina a rationale for organizing student work.

I'm thinking of how to engage the students with the text in ways that highlight its essential features, but parsing it out so they don't have to deal with everything at once. (Blog entry, 26 February 2008)

In this way, Melanie provided Kristina with very explicit mediation. Apparently, based on Kristina's earlier blog entries, the supervisor considered explicit mediation to be the most appropriate form of intervention. Indeed, in her subsequent entry, Kristina reported on how she had incorporated Melanie's ideas into her teaching ("Luckily with some of the advice that Melanie gave me, I re-did the tentative lesson," Blog entry, 11 March 2008). In this entry, Kristina also mentioned the feedback she had received from her mentor: "Elaine was there as well, and she gave me some feedback. She actually said that I did very well and complemented me :)" (Blog entry, 11 March 2008). Here, both the supervisor and the mentor teacher served as expert others mediating Kristina's learning-to-teach.

Self-sought mediation from a peer, the supervisor, and expert knowledge

In a subsequent entry, Kristina reported on how she sought additional assistance from a peer (peer mediation).

The feedback I got back from an observer ... was that the students appeared to again speak more when I was teaching [rather than when her mentor teacher taught]. (Blog entry, 25 February 2008)

In the following entry, Kristina also appealed to expert knowledge (Kennedy, 1999) in order to support her opinion. In particular, Kristina related a comment that one of the ESL students made during the students' discussion of a transcript of a class lecture. In this transcript, the instructor is a native speaker of English and, thus, one of the ESL students proposed that due to this instructor's native-speaker background, she could afford to be friendly and informal with the students. Kristina expressed her disagreement with this student's opinion and appealed to L2 expert knowledge to validate her point of view (the works of Jenkins). In other words, Kristina attempted to verbalize her understandings of the theory and practice of L2 teaching.

One of the female students made a side comment that she believes that the instructor has the luxury to use jokes and be friendly or informal because she was a "native" speaker. I was a bit shocked to hear this since I hear so much of Jenkins and such from our courses.... I figure, NOW, if we just had them practice more and more, so that they could get used to teaching in their own style, wouldn't that be of help? (Blog entry, 25 February 2008)

In response, Melanie suggested that Kristina use this instructional situation as a learning opportunity for the ESL students. In her entry, the supervisor illustrated her point by providing concrete examples of how this could be done. The supervisor's mediation was again very explicit.

It seems like a perfect opportunity for you to create a series of mini-lessons that focus on exactly that-how instructors use jokes or play with language as part of their teaching style ... you could find something on youtube ... or you could even record yourself and listen for how you use metaphors or play with the language as you teach-these sorts of prompts should help to get the conversation rolling. Or you could set up scenarios in which they create an exchange in which they have to use more playful language, try it out, and talk about what sort of socio-pragmatic impact it may have on how students view them. Since they brought this up, it seems like a perfectly acceptable "teachable moment" to me. (Blog entry, 26 February 2008)

Yet, Kristina did not return to these suggestions in her subsequent entries. This unresponsiveness may have resulted from the fact that Kristina did not teach the ESL course by herself. Instead, she taught the course in collaboration with Elaine, which might have limited her opportunities to incorporate new instructional ideas.

Overall, during this period of the teaching practicum, Kristina continued to request assistance from more experts others: her supervisor, her mentor teacher, and she also appealed to expert knowledge (Kennedy, 1999) in order to support her opinion. It is evident that as a novice, Kristina experienced a need for other-regulation and the teaching practicum blog served as a "mediational space" (Wertsch, 1985) through which she could appeal to the mediation of a more expert other, such as her supervisor. In addition, the space allowed Kristina to draw on the theory she had learned during her coursework in reference to her classroom experience (i.e., turning to the works of Jenkins). For her part, during this time period, Melanie continued to provide explicit mediation. For example, she not only supplied Kristina with instructional ideas, but she also provided concrete examples of how certain instructional ideas could be realized. In other words, Melanie demonstrated her sensitivity to Kristina's needs as a learner of teaching.

\section{Emotional dissonance}

During the final period of the teaching practicum, Kristina taught two ESL classes, both of which were observed by her supervisor who provided feedback on them. In the following excerpt, Kristina gives a strong emotional response in relation to the first class Melanie had observed her teach.

So, on Monday I was really disappointed in myself for doing such a horrible job. I noticed myself get pretty nervous while teaching ... and it also didn't help when I wasn't completely prepared. Just because I was nervous, didn't mean I should have jumped from one idea to the next. In reflecting back, I think I set off this frantic pace for myself in my head which made me want to keep rushing things. I realized that one of the things that I needed that day was understanding what my purpose was. It was funny because when I wrote out the first lesson plan, I had a specific objective in mind and could see the flow of the classroom. The actual day I was teaching was another story. I forgot how important it was to keep the purpose in your head at all times. On the other occasions that I taught, I think that was the one reason why my lessons went so smoothly. (Blog entry, 28 March 2008) 
From a Vygotskian perspective, Kristina reported on her experience of emotional dissonance (Golombek \& Johnson, 2004; Olson, 1995), i.e., a strong emotional response to her teaching. For example, she writes, "So, on Monday I was really disappointed in myself for doing such a horrible job. I noticed myself get pretty nervous while teaching" (Blog entry, 28 March 2008). This emotional dissonance was rooted in Kristina's realization of a cognitive contradiction, i.e., a perceived mismatch between her beliefs as a teacher (that she should have an instructional objective in mind) and her practices (she "jumped from one idea to the next").

In her response to this blog entry, Melanie made the following mediational moves. First, she provided Kristina with emotional encouragement: "No one expects you to be 'the perfect' teacher right off the bat" (Blog entry, 29 March 2008). Second, she made concrete suggestions regarding how Kristina could improve her teaching. Specifically, Melanie referred to several pedagogical concepts, such as situating an instructional activity, using instructional paraphrasing, and creating a teaching persona.

Try to begin your lessons by situating the concept or skill you are going to teach in some sort of context that they are familiar with — so for today's lesson, you could have given some directives, both polite and impolite ones, "Could you please stand up?" "Open your books to a blank page.” ... Use instructional paraphrasing: Use students' contributions to build upon and to co-construct meaning in the classroom. Instead of responding with, "OK" or "Anything else?" recast what they have said, relate it to what you are trying to teach them.... In a way, you are trying to build bridges between what they know and what you are trying to teach them.... Develop a comfortable teaching persona: Work on developing a stronger teaching persona. It is one thing to relate to students as a fellow student but you need to establish a teaching persona in which you look and sound like you know what you are doing. Acting "sheepish" or "coy" or "silly" may get a laugh out of them, but you need to establish a sense of authority in the classroom. (Blog entry, 29 March 2008)

In this way, Melanie pushed Kristina to start to think about teaching in conceptual ways and to employ these pedagogical concepts in her teaching. Importantly, the supervisor's mediation was very explicit: she defined some pertinent pedagogical concepts and offered reasons for their importance.

\section{Incorporating Melanie's suggestions and conscious awareness of learning}

During this later period of the teaching practicum, Kristina taught the second ESL class that the supervisor observed. The following excerpt illustrates Kristina's thoughts and feelings in relation to this class.

This time around, following Melanie's advice, I again tried very hard to engage students by not just replying back by saying "okay" or "right"; instead I attempted to rephrase their responses. This was really difficult and I caught myself saying "okay" or "right" sometimes. But making that conscious effort to rearticulate the students' responses was, I think, helpful for me, the students and the class environment. (Blog entry, 21 April 2008)

In this reflection, Kristina returned to the concept of instructional paraphrasing that Melanie had mentioned in her feedback on the first class she observed Kristina teach and reported on how she implemented this concept in teaching. In this way, Kristina showed metacognitive awareness of her learning as a teacher (Yoshida, 2011). By making these moves, Kristina demonstrated her responsiveness to the mediation of the supervisor. From a Vygotskian perspective, Kristina's responsiveness might have been provoked by the emotional dissonance (Golombek \& Johnson, 2004; Olson, 1995) she had experienced after teaching the first class that Melanie observed. According to Poehner (2011), "dissonance represents the sort of inner contradiction that ... creates the potential to push cognitive development" (p. 198). In other words, during that period of the teaching practicum (after the first observation by the supervisor), Kristina was ripe for development, which we witnessed in her reflection on the second class she taught.

In the entry related to her second observation of Kristina's teaching, Melanie affirms Kristina's ability to improve her instructional activities.

What a pleasure to watch you teach today! Your lesson had everything I look for in effective teaching, and more. (Blog entry, 21 April 2008)

The supervisor further noted that Kristina managed to organize her class, situate her instructional activities, use instructional paraphrasing and modeling, and present a competent teaching persona. Again, this entry points to Kristina's responsiveness to the supervisor's earlier mediational moves: she was able to materialize the supervisor's previous suggestions in actual teaching. In order to further promote the novice's learning, Melanie suggested that Kristina pay greater attention to the questions she asks during her classes, noting that her questions are often confusing because they are too broad and vague.

From a sociocultural perspective, the ability to imitate is a central mechanism for internalization (Lantolf \& Thorne, 2006). The supervisor's comments on the second class that Kristina taught suggest that Kristina had succeeded in transforming her teaching on the basis of the pedagogical concepts that her supervisor had described in reference to the first class she had watched Kristina teach. Kristina's engagement in the actual activities of teaching, her agency in appropriating the new mediational means, and the supervisor's mediation lay the foundation for Kristina's potential full internalization of new pedagogical concepts, such as using instructional paraphrasing, situating an instructional activity, and developing an appropriate teaching persona. However, here, there is no evidence that Kristina fully internalized these concepts. That is because, from a sociocultural perspective, only Kristina's re-contextualization of her new understandings of teaching in her future teaching would suggest that these new symbolic means have indeed become the psychological tools that guide her thinking about teaching and her actual teaching activities (Gal'perin, 1977; Leont'ev, 1992). 
In a subsequent entry, Kristina continued to demonstrate her awareness of learning-to-teach (Yoshida, 2011). She not only named a certain instructional practice ("instructional paraphrasing") through expert discourse, but also illustrated that concept. In this particular entry, Kristina presented transcripts of her conversation with her students during the second class the supervisor observed.

Instance 1 Introduction (1 $\mathrm{min})$

Me [Kristina]: So since Elaine talked about closings before a lot and you guys have done it in your office hours and your simulations. So what is a closing and when does it actually happen?

St [A student]: Let audience know it is the end of presentation or discussion.

Me [Kristina]: Right, so, it's basically to tell everyone that something has ended whether it's your presentation or your lecture. So, for instance ...

... as you can see, I still use "right" but! This time around, what I do is REITERATE what the student says. For me, this is important because I had been realizing how important this skill is as a teacher! Also, it's not shown here, but after, I had given examples ... I talked about why it's essential to have closings. (Blog entry, 9 May 2008)

Overall, during this final period of the teaching practicum, Kristina demonstrated her emergent ability to think conceptually about teaching. That is, because she was able to transform her teaching activity (the second class that the supervisor observed) in view of her new understandings of teaching, which were mediated via Melanie's feedback on the first class she observed. It is important to note that Melanie's suggestions were based on several pedagogical concepts (i.e., using instructional paraphrasing, situating an instructional activity, and developing a strong teaching persona), which reflect her attempts to help Kristina develop a more conceptual understanding of teaching. Interestingly, the pedagogical concept of instructional paraphrasing was particularly salient for Kristina. She both employed the concept in her teaching and described how she did so in one of her entries.

\section{Verbalizing her understandings of teaching using expert discourse}

At the very end of her practicum, Kristina observed two other ESL teachers in the same university. One of Kristina's entries during this period illustrates her emergent ability to name certain teaching practices through expert discourse (Golombek \& Johnson, 2004), such as "instructional paraphrasing" and "teaching persona".

She [an ESL teacher Kristina observed] always paused, then rephrased what her students had started and then spun another idea off of the student's.... I realized what the balance between being a teacher and a friend looks like. Unlike my prior teaching experience, she was able to create a persona in which she wasn't demanding or distant with her students, while at the same time maintaining her authority as a teacher. Her quiet and demur personality doesn't make her look weaker in class. Rather, I think that part of her personality makes her students feel welcome. At the same time, I've never seen this side of her where she commands the class. (Blog entry, 8 May 2008)

From a Vygotskian perspective, Kristina's naming of certain teaching practices through expert discourse raised her metacognitive awareness of the teaching activity and also allowed her to re-frame her understanding of teaching (Golombek \& Johnson, 2004). Kinginger (1997) concedes that expert discourse enables teachers to enhance their understandings of teaching. The excerpt above both demonstrates Kristina's awareness of the importance of instructional paraphrasing in teaching and shows her emergent understanding of what it means to create an appropriate teaching persona. Importantly, these two concepts were provided to Kristina by Melanie in her feedback on the first class she observed Kristina teach.

Overall, Kristina's participation in the teaching practicum experience allowed her to externalize her conceptions of teaching and open them to discursive mediation from the supervisor. During her participation in the teaching practicum, Kristina also sought mediation from her mentor (an expert other) and a peer. In addition, Kristina appealed to expert knowledge (Kennedy, 1999) in order to support her opinion. In turn, Melanie provided Kristina with explicit mediation based primarily on relevant pedagogical concepts. In Johnson's (2009) view, "scientific concepts provide both a discourse through which to name experiences and a basis upon which teachers are able to ground their internal rationale for alternative ways of understanding themselves and the activities of teaching" (p. 39). On the basis of the relevant pedagogical concepts provided to her by Melanie, Kristina transformed her teaching activity during the second class that the supervisor observed. Kristina also demonstrated awareness of her learning as a teacher by naming her own teaching practices and the practices of a teacher she observed through expert discourse (Golombek \& Johnson, 2004). These findings suggest that by the end of her teaching practicum experience, Kristina was able to start moving from externally mediated thinking to internally mediated thinking and teaching activities.

\section{DisCuSSION AND CONCLUSIONS}

Overall, the present study demonstrates the transformative power of engagement in writing a dialogic blog for both individual teacher development and teacher education programs. Writing a dialogic blog can function as a powerful tool for self-reflection and systematic examination of everyday teaching practices, and further teacher educators can trace an individual teacher's professional development in this context. In other words, novice teachers' blogs can be useful for monitoring teachers' development, for communicating with teachers on an individual basis, and for supporting and enhancing teachers' professional development strategically, especially if they are dialogic where teacher educators regularly read and respond to what teachers are writing about. Thus, because they have the potential to allow the process of teacher learning to be seen as it unfolds, blogs become valuable resources for teacher educators. Access to 
the inner working of teacher thinking can enable teacher educators to calibrate their mediation and provide struggling teachers with the exact support and expertise they need at any given point in time. However, whether self-directed or dialogic, blogs and teaching journals, as a form of teacher narratives, are considered the most authentic way to understand teaching and teacher learning from the teacher's perspective (Bailey, 1990; Cizek, 1999; Clandinnin \& Connelly, 2000; Doyle, 1997; Lyons \& Labosky, 2002). And, as such, blogs and journals represent a legitimate means of utilizing narrative ways of knowing as a meditational tool to support teacher learning within the context of L2 teacher education programs.

A sociocultural analysis of Kristina's and the supervisor's interactions shows that Kristina moved from otherinitiated mediation in the observation period to self-sought mediation (Kristina requests Melanie's assistance) when she actually began to teach. Kristina begins requesting mediation once she begins to engage in actual teaching. At the end of the teaching practicum, Kristina also demonstrates an emergent ability to think about her teaching conceptually and to base her actual teaching practices on certain pedagogical concepts, such as, for example, "instructional paraphrasing." From a sociocultural perspective, evidence of full internalization lies in a learner's ability to transfer her new understanding to a different context or to efforts to undertake more complex activities (Gal'perin, 1977; Leont'ev, 1992). On the basis of Kristina's blog entries, there is no evidence that Kristina fully internalized the pedagogical concepts offered to her through Melanie's mediation. However, there is evidence of her emergent understanding of these pedagogical concepts. The present study also demonstrates that a supervisor plays a critical role in mediating preservice teacher development of teaching expertise by offering critical emotional support and by providing relevant pedagogical concepts and ideas. In this study, the supervisor's assistance allowed Kristina to re-frame her understanding of teaching and even modify some of her instructional practices on the basis of these new understandings. This transfer of knowledge can be understood as suggesting the effectiveness of the teacher educator's mediation.

Overall, the study suggests that L2 pre-service teachers' narration in dialogic blogs can serve as an important mediational tool that fosters pre-service teachers' development of teaching expertise and underscores the critical role of the supervisor in mediating a novice's learning-to-teach. There are several key arguments for using a dialogic blog for this purpose. Fundamentally, a dialogic blog creates a space in which the relationship can develop and in which assistance can be explicitly asked for and offered. It positions the pre-service teacher and supervisor in dyadic communication. It also appears important that this communication be asynchronous, in that it allows the pre-service teacher to step outside the dizzying flow of teaching in real time and articulate her own perspective on what she has seen and done. Similarly, it offers both parties a space in which to articulate ideas and present and receive feedback in a slow and less-threatening way than the more typical face-to-face meeting after a lesson, in which the pre-service teacher often hears all feedback as criticism.

The analysis also makes clear that the dialogic blog is a place where different sources of expert knowledge for the beginning teacher can come together and, potentially, be taken up in an integrated way. We suspect, however, that the extent to which this actually happens depends primarily on the ability of each party to synthesize and interrogate material from a range of sources. Yet, there is potential, at least, to move beyond the classic divide between classroom preparation for teaching as developing primarily declarative knowledge and initial field experiences as developing primarily procedural knowledge: in the dialogic blog, ideas from the field, classroom, mentor, and peers can act as influences on each other.

Finally, we want to point out the utility of the blog not only as a learning space for Kristina and as a way for Melanie to interact with Kristina but as an important tool for Melanie and other faculty members framing the TESL program as a whole. The dialogue in the blog offers a view of when ideas stressed in coursework find their way into the practicum and when they are left behind; where practicum sites pose helpful challenges and where they pose stifling ones; and where relationships develop to support learning or where they might be helped to develop. We have based this study, in part, on the notion that writing in a dialogic blog helps pre-service teachers by making their thinking explicit to themselves and thus subject to their own revision and development. Yet, the same benefits accrue to us collectively as accrue to the individual: in the dialogic reflective blog, the program faculty as a whole can read a rich dialogue of its members engaged in relationship and learning. This reading, in turn, provides an analytical basis for faculty members to revise existing program practices and develop new ones just as the engagement in the blog provides such a basis for individual teachers to revise and develop their own classroom approaches.

\section{REFERENCES}

[1] Bailey, K. M. (1990). The use of diary studies in teacher education programs. In J. C. Richards \& D. Nunan (Eds.), Second language teacher education (pp. 215-226). Cambridge, UK: Cambridge University Press.

[2] Bigelow, M., \& Ranney, M. (2005). Pre-service ESL teachers' knowledge about language and its transfer to lesson planning. In N. Bartels. (ed.). Applied linguistics and language teacher education (pp. 179-200). New York, NY: Springer.

[3] Bogdan, R., \& Biklin, S. K. (1992). Qualitative research for education: An introduction to theory and methods. Boston, MA: Allyn \& Bacon.

[4] Borg, S. (2006). Teacher cognition and language education. New York, NY: Continuum.

[5] Cizek, G. R. (1999). Narrative and neopragmatism in teacher education and research, in J. Rath \& A. McAninch (Eds) What counts as knowledge in teacher education? Stamford, CT: Ablex Publishing Corporation. 
[6] Clandinin, D. J., \& Connelly, F. M. (2000). Narrative inquiry: experience and story in qualitative research. San Francisco, CA: Jossey Bass Publishers.

[7] Cochran-Smith, M., \& Lytle, S. (1993). Inside/outside: Teacher research and knowledge. New York, NY: Teacher College Press.

[8] Doyle, W. (1997). Heard any really good stories lately? A critique of the critics of narrative in educational research. Teaching and Teacher Education, 13(1), 93-99.

[9] Feiman-Nemser, S. (2001). Helping novices learn to teach: Lessons from an exemplary support teacher. Journal of Teacher Education, 52(1), 17-30.

[10] Gal'perin, P. I. (1977). The problem of activity in Soviet psychology. Theses of papers presented at the 5th all-union pedagogical congress of the Association of Psychologists. Moscow: USSR Academy of Sciences, Part I, pp. 19-40.

[11] Glaser, B., \& Strauss, A. (1967). The discovery of grounded theory: Strategies for qualitative research. Chicago, IL: Aldine.

[12] Golombek, P. R. (2011). Dynamic assessment in teacher education: Using dialogic video protocols to intervene in teacher thinking and activity. In K. E. Johnson \& P. R. Golombek (Eds.), Research on second language teacher education: A sociocultural perspective on professional development (pp. 121-135). New York, NY: Routledge.

[13] Golombek, P. R., \& Johnson, K. E. (2004). Narrative inquiry as a mediational space: Examining emotional and cognitive dissonance in second-language teachers' development. Teachers and Teaching: Theory and Practice, 10(3), 307-327.

[14] Johnson, K. E. (1994). The emerging beliefs and instructional practices of pre-service English as second language teachers. Teaching and Teacher Education, 10, 439-452.

[15] Johnson, K. E. (2009). Second language teacher education: A sociocultural perspective. New York, NY: Routledge.

[16] Johnson, K. E., \& Golombek, P. R. (Eds.). (2002). Teachers' narrative inquiry as professional development. New York, NY: Cambridge University Press.

[17] Johnson, K. E., \& Golombek, P. R. (2003). “Seeing” teacher learning. TESOL Quarterly, 37(4), 729-737.

[18] Johnson, K. E., \& Golombek, P. R. (2011). The transformative power of narrative in second language teacher education. TESOL Quarterly, 45(3), 486-509.

[19] Karpov, Y. V. (2003) Vygotsky's doctrine of scientific concepts: Its role for contemporary education, in A. Kozulin, B. Gindis, V. S. Ageyev, \& S. M. Miller (Eds.) Vygotsky's educational theory in cultural context, pp. 65-82. Cambridge: Cambridge University Press.

[20] Kennedy, M. M. (1999). Ed schools and the problem of knowledge. In J. Rath \& A. McAninch (Eds.), What counts as knowledge in teacher education? (pp. 29-45). Stamford, CA: Ablex.

[21] Kinginger, C. (1997). A discourse approach to the study of language educators' coherence systems. Modern Language Journal, 81(1), 6-13.

[22] Lantolf, J., \& Thorne, S. (2006). Sociocultural theory and the genesis of second language development. Oxford: Oxford University Press.

[23] Leont'ev, A. N. (1981). Problems of the development of the mind. Moscow: Progress Press.

[24] Leont'ev, A. N. (1992). Joint activity, communication, and interaction: Toward a well-grounded "pedagogy of cooperation." Journal of Russian and East European Psychology, 3(2), 43-58.

[25] Lyons, N., \& LaBoskey, V. K. (2002). Narrative inquiry in practice. New York: Teachers College Press.

[26] Mann, S. (2005). The language teacher's development. Language Teaching, 38(3), 103-118.

[27] Numrich, C. (1996). On becoming a language teacher: Insights from diary studies. TESOL Quarterly, 30(1), 131-151.

[28] Olson, M. R. (1995). Conceptualizing narrative inquiry: Implications for teacher education. Teaching and Teacher Education, 11(2), 119-135.

[29] Park, G. (2013). My Autobiographical-Poetic Rendition: An Inquiry into Humanizing our Teacher Scholarship. L2 Journal, 5 (1), 6-18.

[30] Poehner, P. (2011). Teacher learning through critical friends group: Re-contextualizing professional development in a K-5 school. In K.E. Johnson \& P.R. Golombek (Eds.), Research on second language teacher education: A sociocultural perspective on professional development, (pp. 189-203). New York, NY: Routledge.

[31] Schön, D. (1987). Educating the reflective practitioner. San Francisco, CA: Jossey-Bass.

[32] Valsiner, J., \& Van der Veer, R. (2000). The social mind: Development of the idea. Cambridge, MA: Cambridge University Press.

[33] Verity, D. P. (2000) Side affects: The strategic development of professional development of professional satisfaction, in J. P. Lantolf (Ed.) Sociocultural theory and second language learning, pp. 179-198. Oxford: Oxford University Press.

[34] Vygotsky, L. S. (1963/1934). Thought and language. Cambridge, MA: MIT Press.

[35] Vygotsky, L. S. (1978). Mind in society. Cambridge, MA: Harvard University Press.

[36] Vygotsky, L.S. (1987). Thinking and speech. In R. W. Rieber \& A. S. Carton (Eds.), The collected works of L.S. Vygotsky (Vol. 1, pp. 37-285). New York, NY: Plenum.

[37] Wertsch, J. V. (1985). Vygotsky and the social formation of the mind. Cambridge, MA: Harvard University Press.

[38] Yoshida, T. (2011). Moodle as a mediational space: Japanese EFL teachers' emerging conceptions of curriculum. In K. E. Johnson \& P. R. Golombek (Eds.), Research on second language teacher education: A sociocultural perspective on professional development (pp. 136-152). New York, NY: Routledge.

Ekaterina Arshavskaya is originally from Moscow (Russia). Her MA studies took place in the applied linguistics program at the Montclair State University (NJ) in 2008 and she got her PhD in applied linguistics at Penn State in 2013.

She has worked as an EFL/ESL instructor for over 11 years. Her previous work assignment took place at Penn State where she taught academic writing courses to both undergraduate and graduate international students as well as worked with the International 
Teaching Assistants (the ITAs). Currently, she is an assistant professor of English as a Second Language (ESL) at the Utah State University (Logan, UT). Her research interests include second language (L2) writing and pre- and in-service L2 teacher education.

Dr. Arshavskaya is a member of the American Association of Applied Linguistics (AAAL) and Teaching English to Speakers of Other Languages (TESOL).

Anne Elrod Whitney is originally from Houston, Texas (USA). She received her BA in English in 1996 at the University of New Mexico (USA), her M.Ed. in education in 1999 at Kent State University (Ohio, USA), and her Ph.D. in education in 2006 at the University of California, Santa Barbara (USA).

She is a former secondary school English teacher and college writing instructor. She is currently an Associate Professor of Education in the department of Curriculum and Instruction at the Pennsylvania State University (State College, PA, USA). She has published extensively in such journals as Research in the Teaching of English, English Education, English Journal, Teachers and Teaching: Theory and Practice and many others. Her research focuses on written composition, the teaching of writing, and teacher professional development in language arts.

Dr. Whitney currently serves as associate editor of the Journal of Teacher Education. Affiliated with the National Council of Teachers of English, the National Writing Project, the Conference on English Education, the International Society for the Advancement of Writing Research, and the American Educational Research Association, she has won the CEE Janet Emig Award, the AERA/Writing and Literacies SIG Cahir Award, and the CEL Best Article Award. 